\title{
Een nieuwe methode om de slaagkans van therapie bespreekbaar te maken
}

Het voorspellen van behandeluitkomsten is een onderbelicht facet van het klinisch handelen. Ondanks toenemende aandacht voor klinische significantie van bevindingen in uitkomstonderzoek ontbrak een methode om helder te communiceren over behandeleffectiviteit van therapie. In dit artikel bespreken we een nieuwe methode, de probability of treatment benefit tabel, die zich leent om op een eenvoudigere manier te communiceren over behandeluitkomsten.

door Ernst H.W. Koster, Kaat Defreyne, Laura De Putter \& Anouk Vanden Bogaerde

In druk: Psychopraktijk

Dr. E. Koster is als Universitair Docent verbonden aan de Universiteit Gent, Vakgroep ExperimenteelKlinische en Gezondheidspsychologie (ernst.koster@ugent.be); K. Defreyne en L. De Putter zijn masterstudenten verbonden aan de Universiteit Gent; Dr. A. Vanden Bogaerde is als doctorassistent verbonden aan de Universiteit Gent, Vakgroep Experimenteel-Klinische en Gezondheidspsychologie. 
Een interessant gedachtenexperiment voor de psycholoog. Stel, u moet een ingrijpende medische ingreep ondergaan. $U$ heeft de volgende vragen voor uw specialist: (1) wat is de kans dat de ingreep zal slagen?; (2) zal ik volledig herstellen na mijn operatie?; (3) zijn er risico's verbonden aan de operatie? Logische vragen waarop u een antwoord mag verwachten van de specialist zelfs voordat $u$ ze expliciet bevraagt. Verplaatst u zich nu naar uw eigen psychologische praktijk. Wat als uw cliënten u dezelfde (logische) vragen stellen? Zou u ze kunnen beantwoorden? Over het algemeen weten we vaak geen of een vrij onnauwkeurig antwoord te formuleren op deze essentiële vragen. 'Dat is per individu verschillend en is afhankelijk van heel wat factoren, bijvoorbeeld de motivatie van de cliënt", zeggen we dan vaak. Als onze medische specialist een dergelijk antwoord zou formuleren, zullen de meesten onder ons de operatie afblazen en een second opinion zoeken. Echter, bij psychologische behandelingen stellen we vaak weinig vragen bij ons beperkte zicht op onze eigen effectiviteit. Een intrigerende observatie die om een verklaring vraagt. Weten we dan echt zo weinig over de effectiviteit van onze behandelingen?

Het antwoord op deze vraag is verrassend. Eigenlijk weten we vanuit huidig behandelonderzoek heel veel over de effectiviteit en de grootte van de effecten. Dit wordt uitgedrukt in verschillende statistische begrippen. De grootte van het effect van een behandeling bij een bepaalde groep of steekproef wordt uitgedrukt met effect size. Hierin wordt de grootte van een verandering in het gemiddelde van die groep gedeeld door de standaard deviatie. Er zijn verschillende manieren om effect size te berekenen en voor die verschillende vormen van effect size zijn er richtlijnen over wanneer men spreekt van een klein, een middelmatig of een groot effect. Hoewel effect sizes cruciaal zijn bij het rapporteren van behandelonderzoek, is deze maat in onze dagelijkse communicatie naar cliënten erg onhandig. Cliënten uitleggen dat ze waarschijnlijk 1.2 standaard deviatie zullen opschuiven, zal niet direct hun vraag beantwoorden. Hetzelfde geldt eigenlijk voor andere veelgebruikte manieren waarop in behandelonderzoek gerapporteerd wordt over de grootte van een behandeleffect. Oddsratios, reliable change index, numbers needed to treat, betrouwbaarheidsintervallen; allemaal heel waardevol binnen behandelonderzoek maar nauwelijks 
bruikbaar in de communicatie met cliënten of andere betrokken partijen (psychologen onderling, verzekeraars, etc.).

Een tweede belangrijk probleem is dat veel van de bovenvermelde maten om de grootte van een effect aan te geven niet zijn aangepast aan de individuele verschillen tussen cliënten. De gerapporteerde maten doen uitspraken op groepsniveau waardoor het niet gemakkelijk is om te voorspellen hoe groot het effect van een behandeling gaat zijn bij een specifieke cliënt. Het is onmogelijk om rekening te houden met alle individuele variabiliteit en complicerende factoren, maar om deze factoren totaal niet in rekening te brengen lijkt op zijn minst even problematisch.

Een recent artikel van Lindhiem ea (1) stelt een nieuwe manier voor om de voorspelling van effecten van therapie efficiënt te communiceren waarbij veel van de bovenvermelde problemen opgelost worden. We willen graag de basisideeën uit dit artikel bespreken en aangeven waarom deze methode een belangrijke stap voorwaarts is. De methode die zij voorstellen is de 'Probability of Treatment Benefit (PTB)' tabel. De PTB tabel is zoals de naam al aangeeft probabilistisch: het geeft de kans aan dat een behandeling effecten sorteert. Bovendien is ze geïndividualiseerd: de ernst van de problemen bij aanvang van de behandeling wordt gezien als de meest bepalende factor bij het voorspellen van de kansen op verbetering. Om deze methode goed te begrijpen zetten we een aantal uitganspunten van Lindhiem en collega's op een rijtje.

\section{Uitgangspunten}

Een eerste uitgangspunt dat centraal staat volgens Lindhiem en collega's, is dat er een onderscheid is tussen normalisatie en respons ten opzichte van een behandeling. In onze communicatie met cliënten wordt onderscheid tussen respons op behandeling en uiteindelijke behandelingsuitkomst ('normalisatie') vaak uit het oog verloren. Respons op behandeling duidt op de hoeveelheid verandering die een behandeling bij een cliënt teweegbrengt: het verschil tussen de ernst van 
problematiek na behandeling in vergelijking met de problematiek bij aanvang. Bijvoorbeeld zou een cliënt bij aanvang van de behandeling een score van 27 kunnen hebben op de Beck Depressie Vragenlijst (BDI; (2)), en na behandeling een score van 13. Meestal betekent de respons op een behandeling een verbetering zoals in het bovenstaande voorbeeld, maar behandeling kan ook geen effect hebben of zelfs leiden tot verslechtering (3). Normalisatie is de status na behandeling. Een score van 13 op de BDI is bijvoorbeeld een zogenaamde subklinische score, oftewel een score die geobserveerd wordt bij personen die geen depressie hebben. Mensen starten vaak met problematiek waarbij hun functioneren binnen de klinische range valt, dus binnen de range die geobserveerd worden bij cliënten met een klinische diagnose. Men beoogt met behandeling het functioneren te verbeteren waardoor men binnen de range komt van de 'gezonde' populatie. Verschillende maten van klinisch significante verandering richten zich op dit aspect van uitkomst na therapie.

Onderzoek heeft uitgewezen dat ernst van de problematiek bij aanvang de respons en behandeluitkomst op een betrouwbare manier kan voorspellen (4). Ook Lindhiem ea (5) stellen dat de problematiek bij aanvang cruciaal is in relatie tot respons en uitkomst: ernstigere symptomen bij aanvang zijn vaak geassocieerd met een grotere respons op behandeling maar een zwakkere behandelingsuitkomst. Bijvoorbeeld, een cliënt met een hoge BDI score zal waarschijnlijk een groter effect hebben bij behandeling in termen van hoeveel zijn BDI score zakt dan een cliënt met een lagere BDI score. Maar de kans dat de eerste cliënt tot een 'gezonde' populatie behoort na behandeling, is kleiner dan de cliënt met de lagere aanvangsscore. Dus iemand met ernstige symptomen kan veel vooruitgang boeken maar na behandeling nog altijd in de klinische range vallen, terwijl iemand met minder ernstige symptomen gemakkelijker naar de 'gezonde' range verschuift zonder dat er noodzakelijk veel verbetering is verwezenlijkt. Samengevat, het symptoomniveau kan voor elke cliënt bepaald worden en zo kan men een meer geïndividualiseerde voorspelling doen over de voordelen van een therapie voor een cliënt. 
Een tweede uitgangspunt dat Lindhiem en collega's centraal stellen is dat behandeluitkomst en respons worden uitgedrukt in kansen en percentages. Aangezien er altijd onzekerheid bestaat over het aanslaan van een therapie is het gebruik van kansen het meest correct. De kans op verbetering wordt berekend op basis van de gegevens die gevonden worden in onderzoek naar de effectiviteit van een bepaalde behandeling bij een bepaalde populatie. Zo wordt bijvoorbeeld de onderzochte populatie ingedeeld naargelang de ernst van de aanvangsscore. Er wordt een variabele die gerelateerd is met behandeluitkomst geselecteerd en op basis daarvan wordt de populatie ingedeeld (dit kan bijv. de ernst van de aanvangsscore zijn). Bij deze verschillende groepen wordt er nagegaan welk percentage na behandeling tot de 'gezonde populatie behoort. Tevens wordt nagegaan welk percentage van de steekproef een klinisch significante verbetering vertoond. Voor veel mensen zijn dergelijke percentages een stuk gemakkelijker te begrijpen dan bv. effect sizes. Bovendien geven ze ook een beter beeld van wat een cliënt kan verwachten. Ze zeggen namelijk niet hoe groot het effect is van een behandeling, maar wat de kans is dat die behandeling voordelen zal hebben voor die bepaalde cliënt. Dus op basis van de resultaten van uitkomstonderzoek kan men een range aangeven waarin de verwachte effecten van therapie kunnen vallen.

\section{Hoe ziet het overzicht er uit?}

Een voorbeeld van de PTB tabel vindt $u$ in Figuur 1. Deze data zijn gebaseerd op uitkomsten van een onderzoek naar de effectiviteit van psychologische behandeling van gedragsproblemen bij jongeren. Hierbij staat in functie van de ernst van de aanvangsproblemen ( $y$-as) weergegeven wat de kans is dat iemand na behandeling valt in de gezonde of in de klinische range. Eveneens staat er uitgedrukt wat de kans is op verbetering of verslechtering. Uit de tabel wordt duidelijk dat op grond van behandelonderzoek (6) blijkt dat een jongere met een hoge aanvangsscore op de $\mathrm{CBCL}$ Externaliserende problemen (80+) maar $9 \%$ kans heeft om in de 'gezonde' range te komen na behandeling. Maar is er wel $64 \%$ kans dat er verbetering zal optreden terwijl de kans op 
verslechtering onbestaande is. Een jongere met een lagere aanvangsscore, bijvoorbeeld een score tussen 65 en 69, heeft $41 \%$ kans om in de gezonde range terecht te komen na behandeling, maar de kans dat er verbetering ten aanzien van het aanvangsniveau zal komen is maar $38 \%$ terwijl er $7 \%$ kans is dat er verslechtering zal optreden. Aan de hand van de PTB tabel kan een therapeut samen met ouders en het kind duidelijk bespreken welke effecten te verwachten zijn bij therapeutische interventies.

\section{Waarom achten we deze methode zo belangrijk?}

Dit is één van de eerste methoden waarmee we cliënten snel en gemakkelijk inzicht kunnen geven in de kans op verbetering op een manier die gemakkelijk te begrijpen is. Geen van de eerdere maten van effect size leende zich ertoe om gemakkelijk met cliënten te bespreken wat de te verwachten resultaten van een therapie zijn. Deze methode verbetert dit drastisch. Natuurlijk is het een voorspelling met een foutmarge en zijn er allerlei factoren die voor meer of minder gunstige effecten kunnen zorgen, maar het geeft tenminste een duidelijk beeld. Omdat cliënten het recht hebben om correct geïnformeerd te worden en de hier besproken methode dit ook mogelijk maakt, pleiten we ervoor dat binnen de verschillende vormen van therapie wordt nagegaan hoe inzicht in de te verwachten effecten een vast onderdeel kan vormen bij indicatiestelling en adviesgesprekken. Een dergelijke PTB tabel als supplement bij behandelrichtlijnen zien we in deze context als een bruikbaar hulpmiddel. Hierbij dient natuurlijk goed nagedacht te worden op welke manier dit het beste therapeutisch besproken kan worden.

De brede toegankelijkheid van verwachte therapeutische effecten is niet enkel relevant in de directe communicatie met cliënten maar ook in het overleg met verschillende partijen in de GGZ. Deze methode kan een belangrijk hulpmiddel vormen bij de communicatie over verwachte baten (en kosten) van psychologische behandeling met verschillende actoren zoals de overheid, verzekeringen en andere hulpverleners. In die zin zou deze methode aanzet kunnen geven tot een transparantere 
communicatie binnen de psychologische hulpverlening over wat mensen wel en niet kunnen verwachten van hulpverlening.

Tot slot

Het is duidelijk dat er nog altijd afstand is tussen de klinische praktijk en het wetenschappelijk onderzoek. In het behandelonderzoek realiseert men zich de afgelopen jaren gelukkig dat er meer stappen noodzakelijk zijn om verspreiding van inzichten uit onderzoek te faciliteren. Toch is men er vooralsnog binnen het wetenschappelijk onderzoek maar matig in geslaagd om informatie aan te bieden die gemakkelijk te begrijpen is voor de behandelaar en cliënt in de klinische praktijk. In de klinische praktijk is de hoeveelheid tijd om literatuur door te nemen nu eenmaal beperkt en vormen allerlei nieuwe, state-of-the-art statistische methoden een afknapper. Vandaar ons enthousiasme voor een methode die toestaat dat wetenschappers en clinici dezelfde taal spreken.

\section{Noten}

(1) Lindhiem O ea (2012) Predicting psychotherapy benefit: A probabilistic and individualized approach. Behavior therapy 43: 381-392

(2) Beck AT ea (1996) Beck Depression Inventory-Second edition (BDI-III. San Antonio, TX: The Psychological Corporation

(3) Barlow DH (2010) Negative effects from psychological treatments: A perspective. American psychologist 65: 13-20. doi: 10.1037/a0015643

(4) Kazdin AE \& Whitley MK (2006) Comorbidity, case complexity, and effects of evidence-based treatment for children referred for disruptive behavior. Journal of consulting and clinical psychology 74: 455-467. doi: 10.1037/0022-006X.74.3.455; Lindhiem O \& Kolko DJ (2011) 
Trajectories of symptom reduction during treatment for behavior problems in pediatric primary-care settings. Administration and policy in mental health and mental health services research 38: 486-494. doi: 10.1007/s10488-011-0335-2; Reyno SM \& McGrath PJ (2006) Predictors of parent training efficacy of child externalizing behavior problems - a metaanalytic review. Journal of child psychology and psychiatry 47: 99-111. doi: 10.1111/j.14697610.2005.01544.x

(5) Zie noot 1

(6) Kolko DJ ea (2009) Community vs. clinic based modular treatment of children with early-onset ODD or CD: A clinical trial with 3-year follow-up. Journal of abnormal child psychology 37: 591-609. doi:10.1007/s10802-009-9303-7

(7) Met toestemming uit Lindhiem ea, zie noot 1 


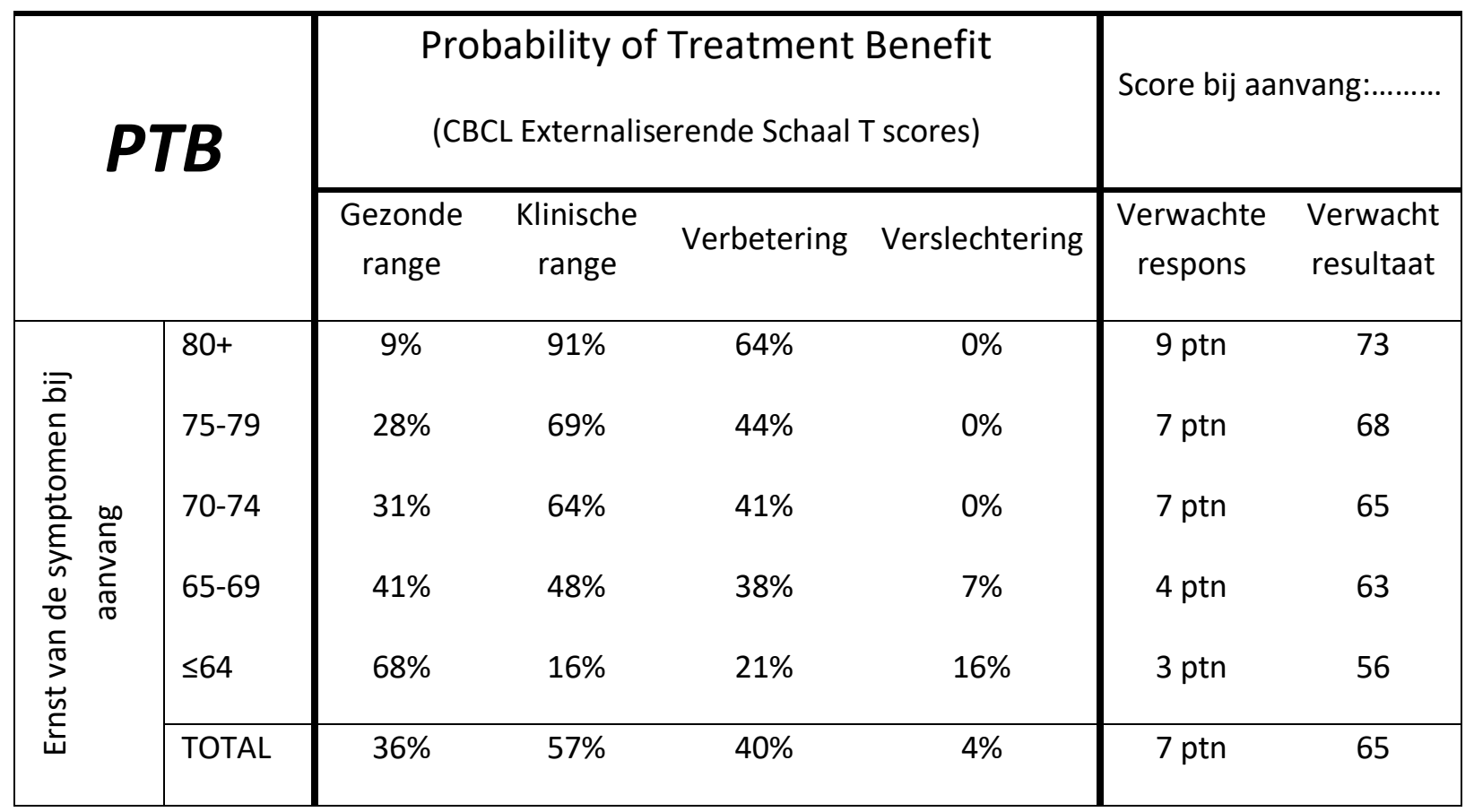

PTB Tabel (7) 
